\title{
Potential effects of the EU's carbon border adjustment mechanism on the Turkish economy
}

\author{
Sevil Acar ${ }^{1} \cdot$ Ahmet Atıl Aşıcı $^{2}$ A. Erinç Yeldan ${ }^{3}$ (D
}

Received: 7 March 2021 / Accepted: 18 August 2021 / Published online: 31 August 2021

(c) The Author(s), under exclusive licence to Springer Nature B.V. 2021

\begin{abstract}
In December 2019, the EU announced the European Green Deal (EGD) to create a climateneutral continent by 2050. Accordingly, the EU Emission Trading System (ETS) will be revised to maintain economic growth against possible losses in competitiveness, leading to "carbon leakage." Carbon border adjustment (CBA) is one of the mechanisms proposed to tackle the carbon leakage problem. In this paper, we provide a first-order estimate of the potential impacts of a possible CBA across production sectors and build a dynamic, multisectoral applied general equilibrium (AGE) model to study the overall macroeconomic impact of the EGD on the Turkish economy. Then, we extend our analysis to document the potential benefits of a more active climate policy. The model is in the Walrasian tradition wherein aggregate supply and demand actions are simulated with the interplay of relative prices to bring equilibrium in the markets for goods, for labor, and for foreign exchange. Constructed around 24 production sectors, the model accommodates flexible, multi-level functional forms to link production activities with gaseous emissions, a government entity to maintain taxation, and public expenditures, as well as administration of environmental policy instruments, all within an open-economy macroeconomic environment. Our results suggest that the potential adverse impact of the CBA on the Turkish economy would range between 2.7 and 3.6\% loss of the GDP by 2030 over the business-as-(un)usual base path. We also document that under an alternative scenario through which Turkey is modeled as an active agent in the international climate policy arena embedding decarbonization into her official macroeconomic policy agenda, she can achieve a superior pathway for national income and a reduced carbon burden.
\end{abstract}

Keywords European green deal · Carbon border adjustment · Turkey · Input-output methodology $\cdot$ Applied general equilibrium

This paper is based on research prepared for Turkish Industry and Business Association (TÜSİAD), and a previous version has been presented at the 27th Meetings of the Economic Research Forum (ERF), 14-15 June, 2021. The authors wish to acknowledge their indebtedness to Burcu Ünüvar, Ebru Voyvoda, Izzet Ari, and participants to the ERF Conference as well as to seminars at Kadir Has, Boğaziçi, and Marmara Universities for their valuable comments and suggestions on earlier versions of this study. All views are solely of the authors, and all usual caveats apply.

Author names are in alphabetical order and do not necessarily imply authorship seniority.

Extended author information available on the last page of the article 
JEL classification $\mathrm{C} 67 \cdot \mathrm{C} 68 \cdot \mathrm{Q} 56$

\section{Introduction}

In December 2019, the EU announced the European Green Deal (EGD), whose ultimate target is to create a climate-neutral continent by 2050 . With the EGD, reduction targets of greenhouse gases (GHGs) were declared with more ambition, and the EU industry was announced to be reorganized around the circular economy principles.

Broadly set within the auspices of the Communication by the European Commission, the EGD is presented "as a new growth strategy that aims to transform the EU into a fair and prosperous society, with a modern, resource-efficient and competitive economy where there are no net emissions of greenhouse gases in 2050 and where economic growth is decoupled from resource use" (European Commission, 2019).

Combining ambitious climate mitigation targets of zero net greenhouse gas emissions by 2050, a viable industry working under the principles of energy efficiency and circularity, and aiming for a fair, healthy and environmentally food system under farm to fork management, the EGD purports "to put sustainability and the well-being of citizens at the center of economic policy, and the sustainable development goals at the heart of the EU's policymaking and action" (European Commission, 2019). Thereby, The EGD is regarded, in the words of Gaventa (2019), "as a climate project, aimed at making Europe a climateneutral continent; as a social project, to support a just transition; as an economic project, seeking to rejuvenate EU investment and competitiveness; as a European project, to give new purpose and unity to the EU; and as an international project which will take a more geopolitical approach to global climate security."

EGD focuses on three basic priorities regarding industrial strategy: a world-leading and globally competitive industry, an industry oriented toward the goal of becoming climateneutral and preparing for and transition to the digital future. Additionally, it intends to achieve this transition within the framework of the circular economy. The policy tools to enable such a transition include regulation, standardization, investment, innovation, reform, dialogue with stakeholders, and international cooperation. The European Climate Regulation is expected to serve as a guiding and overseeing role with respect to energy and climate regulations in the context of EGD. For this purpose, existing regulations surrounding the ETS are stated to be revised by mid-2021 at the latest. Existing regulations are expected to be updated in light of these revisions.

According to the European Commission, effective pricing of carbon throughout the economy is an essential precondition for achieving climate-related goals. For this purpose, the EU established the ETS and has been issuing each year ever falling emission quotas to specific industries. Implemented through the market-determined "carbon pricing" mechanism, this system requires producers operating in the relevant industries to obtain such quotas in the trading markets, in case their emission levels exceed the limits they were assigned. Over the period 1990-2018, the EU was able to cut its greenhouse gas emissions by $23 \%$, even though its economy grew by $61 \%$. The EU plans to curb greenhouse gas emissions by the year 2030, by approximately 50-55\% compared to 1990 levels, and to reach that target through a review of all its climate-related policies.

Accordingly, the EU's Emission Trading System (ETS) will be revised to keep economic growth and employment strong against possible losses of competitiveness due to an increase in carbon price under ETS, a problem called "carbon leakage." Carbon 


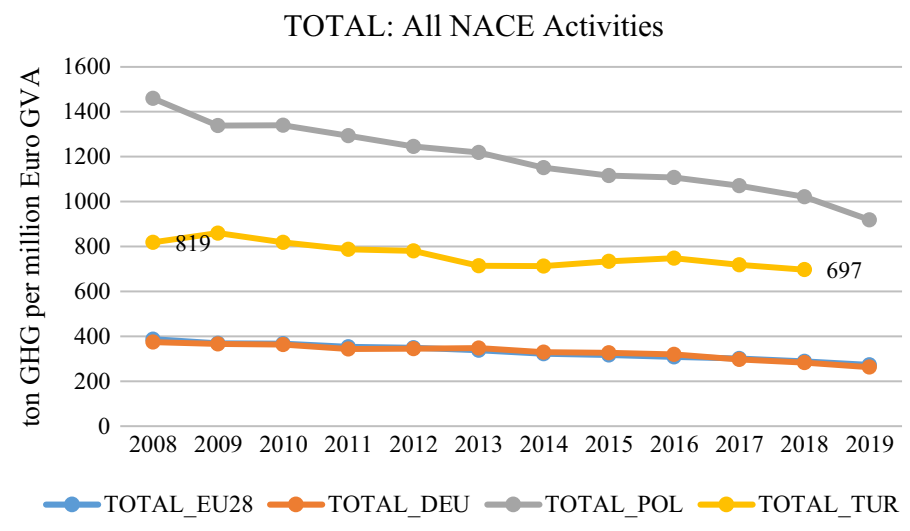

Fig. 1 GHG per gross value-added (ton CO2e/million euro). Source: Eurostat and authors' calculations

border adjustment (CBA) is one of the alternative mechanisms proposed to tackle the carbon leakage problem. CBA, in essence, is expected to serve as an import fee levied by the carbon-taxing region (in this case, the EU) on goods manufactured in noncarbon-taxing countries (in this case, Turkey). CBA is expected to have a considerable effect on the emission-intensive Turkish exports (Yeldan et al., 2020) as the EU continues to be the top destination of Turkish exports (accounting for $47 \%$ of the total in 2018).

Minimizing the costs incurred by the CBA requires decoupling of emissions from economic growth. Figure 1 shows the evolution of the GHG intensity of the Turkish economy as measured by the tons of GHGs per million euro gross value-added created (GVA, chain-linked volumes-2005) in comparison with those of EU28, Germany, and Poland.

While the decrease in the overall GHG intensity of the Turkish economy (all NACE activities) from 819 in 2008 to 697 tons of GHG per million euro GVA in 2018 indicates a relative decoupling of the economic growth from the GHG emissions, it is still more than double than that of EU28 and Germany, and the decline is not as fast as that of Poland.

To the best of our knowledge, the quantitative impacts of a possible CBA on the Turkish economy have not been analyzed so far. The current study is a first attempt to model and estimate the immediate upon-impact effects of a CBA mechanism on the Turkish industry, agriculture, mining, and services sectors. It is also a pioneer in investigating the dynamic effects of a CBA mechanism on the major macroeconomic indicators for a period spanning from 2020 to 2030. The purpose of this paper is twofold: First, we provide a firstorder estimate of the potential sectoral impacts of a possible CBA on the Turkish economy by employing the input-output methodology. Next, we build a dynamic, multi-sectoral applied general equilibrium (AGE) model by embedding sectoral CBAM tax rates obtained at the first stage to study the economic impact of the EGD on the Turkish economy, and the potential benefits to be reaped by pursuing a more active climate policy.

The plan of the paper is as follows: After summarizing the relevant literature in Sect. 2, we calculate the carbon bill that Turkish exporters are expected to pay for the embedded carbon in Turkish exportable products to the EU market by employing an input-output analysis in Sect. 3. In Sect. 4, we present our AGE model and report the 
results of various alternative scenario environments. Section 5 concludes with due policy proposals.

\section{Literature review}

The ETS, as a carbon pricing mechanism, certainly affects the costs incurred by the manufacturers in the EU, and thus, their competitiveness in the EU and international markets. It can be foreseen that the EU manufacturers would react to such an arrangement in various ways, based on the characteristics of the product (in terms of carbon intensiveness and trade volumes). While certain industries (e.g., road transportation) that are unable to avoid regulation will have to incur extra costs for their greenhouse gas emissions, others (such as iron and steel, or cement production), which are characterized by significant levels of foreign trade, will likely be inclined to move their operations to countries where carbon regulations are laxer. For the EU, this poses two distinct problems. First of all, a not-so-insignificant volume of production and employment would be lost to overseas, as a direct consequence of the carbon emission regulation. Secondly, any manufacturer that would have to incur the obligation to cut back its emissions would be free to move outside the EU and continue its operations elsewhere maintaining its original emission levels. Thus, the impact of any system designed to lower greenhouse gas emissions within the EU would have only limited success on a global scale. The literature refers to this problem as "carbon leakage."

Clearly, the threat of carbon leakage is an issue that rises out of the contrast between regions/countries that do or do not implement effective carbon regulations. Hence, one of the most strategic decisions of the EGD, in the context of reducing carbon leakage, is the mechanism of carbon adjustment at the border. The purpose of this mechanism is to eliminate any discrepancies of carbon costs across the traded goods, through an adjustment procedure to be applied at the border (Neuhoff, 2011). Even though the specifics of the mechanism, as well as the industries it will be targeting, have yet to be clarified, the carbon contents of the goods awaiting entry through the borders of the EU shall be subjected to a surcharge, if they were not taxed or priced earlier at their country of origin, or to a discount, if the tax or pricing applied at the country of origin was higher than the figure required by the EU.

The novelty of the current study originates from the fact that the quantitative impacts of a possible CBA on the Turkish economy have not been analyzed so far. This is a first attempt to model and estimate the static impacts of a CBA mechanism on the sectors and to project the dynamic effects on the major macroeconomic indicators through 2020-2030. Another novelty of our analysis is that it offers a consistent micro-sectoral extension to the official INDC pledge offered in the Paris 2015 COP meetings which was constrained in its depiction of an across-the-board, blanket target of $21 \%$ reduction in total gaseous emissions. This official target was set against an exogenously determined base path (over 2015-2030). Yet, except for a list of popular policy recommendations, there was no road map, nor any analytical blueprint on how to achieve this overall aggregate target wherein the burden of the necessary adjustments would be shared across the production sectors of the domestic economy. The Preparation for Market 
Readiness (PMR) project ${ }^{1}$ report that had been completed recently, on the other hand, focused almost exclusively on the energy sector rather as only a technical activity analysis and was not developed within a general equilibrium focus studying macroeconomic flows in response to market signals.

There is a line of previous modeling research to investigate the economic impact of instruments of mitigation of climate change and to reduce greenhouse gas emissions in Turkey. These studies were usually based on computable general equilibrium (CGE) models. For instance, in a study on how climate-change mitigation policies with a focus on sustainable development and employment can be designed, Bouzaher et al., (2015) model cutting emissions by way of a carbon tax coupled with an active green innovation strategy stimulated through R\&D. Such innovation activities are assumed to be based on a technology abating $\mathrm{CO}_{2}$ concentrations caused by burning fossil fuels, through bringing about savings regarding energy input. They find that, by the year 2030, the policy package would bring about a $2 \%$ increase over BAU figures with a $23 \%$ reduction in overall greenhouse gas emissions.

A comprehensive study published by the WWF (Voyvoda et al., 2015), analyzes the potential impact of the three basic policy tools described in the following, in the context of the scenario titled "Climate Policy Package."

- Introducing a carbon tax.

- Channeling these taxes, through a renewable energy investment fund, to projects aiming to generate renewable energy.

- Autonomous increases (based on technological developments and market conditions, regardless of any policies designed to increase efficiency levels) in energy efficiency.

In this context, by 2030, the overall $\mathrm{CO}_{2}$ emission levels of Turkey will be reduced

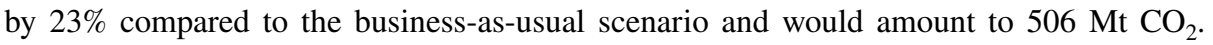
Thanks to these mechanisms, the carbon intensity in the economy (annual $\mathrm{CO}_{2}$ emissions/ GDP) can also be reduced by $20 \%$. The authors underline the fact that well-designed social policy packages can be used to improve income distribution and managing fluctuations in employment to minimize negative effects.

Following their steps, Acar and Yeldan, (2016) review the effect of phasing out the existing production and investment subsidies offered for coal mining and coal-based power plants in Turkey and argue that subsidies on coal not only pose a burden on the government's budget but also discourage the development of renewable energy production mechanisms. In their analysis, they find that the simple elimination of the existing subsidies destined for coal would lead to $5.4 \%$ lower greenhouse gas emissions compared to BAU projections by the year 2030, with only a modest $0.5 \%$ reduction in GDP.

A report published by the Turkish Industry \& Business Association (TÜSİAD) in 2016 (Yeldan et al., 2016) analyzes the potential economic impact of carbon taxes which may be introduced in Turkey, to reduce emission levels. According to the scenario, taxes amounting to $4.7 \%$ of the GDP are introduced to achieve the goal of " $21 \%$ emission reduction compared to BAU levels by 2030" as declared in Turkey's INDC. The report finds that these efforts would also cause an $8.7 \%$ drop in national income compared to the reference scenario, by 2030 . The production loss projected in this analysis reveals that an emission

\footnotetext{
1 See https://pmrturkiye.csb.gov.tr/ for a more detailed inforamtion and documentation on the PMR Project research flow.
} 
reduction strategy based solely on taxes on emissions would certainly pose a burden on the economy. With reference to this observation, the authors propose a balancing cut in other taxes through a "neutral tax" as a means to provide some stimulation in the face of the burden posed by the energy tax. This alternative approach entails the same level of taxation on energy, and coupled with a comparable reduction on employment taxes, succeeds to provide a boost to employment and the aggregate economy. In their analysis, the potential employment creation opportunities of the climate package entail welfare gains originating from increased employment and rationalization of the industrial structure away from fossil-fuel based energy production to one of renewables. The imposition of the carbon tax is accommodated with a reduction in employment taxes (generating a neutral fiscal effect); this leads to a second best gain in employment demand and welfare.

In contrast to the above-mentioned studies, Kat et al. (2018) engage in an analysis of the potential effects of an ETS in Turkey, based on the assumption that planned subsidy mechanisms on nuclear energy and renewable energy are maintained. In this context, they predict that emission levels $30 \%$ lower than the BAU scenario presented in the INDC could be achieved by 2030 . In the absence of other policy measures, their model predicts up to $6 \%$ contraction in energy-intensive industries, coupled with $1.5 \%$ contraction in transportation and $0.1 \%$ contraction in services, while other industries would expand by $0.5 \%$ on average, compared to BAU figures.

Acar, Voyvoda and Yeldan (2018) come up with a "green development pathway policy package" stipulating a comprehensive green development strategy of discontinuation of coal subsidies; imposition of a producer-pays-principled carbon tax; expansion of investments destined to renewable energy, financed by the tax monies; and generating autonomous energy efficiency gains. They report that, by 2040, the proposed green development pathway could lead to up to a 7\% higher level of GDP compared to the base-path figures, along with lower unemployment, reduced levels of the gray economy, and a higher rate of overall income.

In addition to the CGE-based modeling analyses, many independent studies questioned the sustainability of Turkish growth pathways from the viewpoint of natural capital and resource use. Acar and Gültekin-Karakaş (2016), for instance, note that Turkey's growth path had been achieved at the expense of rapid natural resource use and increased environmental pollution in violation of basic sustainability criteria.

Turkey's official INDC declaration envisaged that the GHG emissions for the reference scenario would reach 1,175 million tons by 2030. Figure 6 provides a comparison of the two policy environments-one with no policy intervention (the reference scenario) and another with certain policy interventions (various climate and complementary policy instruments) as presented in the above-mentioned literature. These findings suggest that the failure to introduce policy changes in response to climate change along with a failure to embrace the new green economic order could pose significant emission costs for Turkey.

The findings presented in the literature imply that implementing an active climate policy would be beneficial for Turkey from every perspective and would potentially bring about egalitarian and sustainable results. Therefore, one can forcefully claim that effective pricing of greenhouse gas emissions, discontinuation of subsidies on coal, and the use of revenues for the development of renewable energy industries, green innovation, and green businesses strategically positioned in the context of regional development programs, would help Turkey in both lowering emission figures and increasing income and employment levels in a more egalitarian and sustainable route to development. The negative effects certain industries would suffer in the face of such climate policies can be remedied through tax benefits and advantages offered through the neutral tax perspective described above. All 
these points lead to the conclusion that emission reduction policies introduced as an element of a consistent and climate-change-sensitive program could foster structural change and industrialization in the context of both developed and developing countries.

Turkey supplied a total of 192.5 billion euros worth of exports of goods and services in 2018. The EU continues to be the top destination of Turkish exports, having the highest share in aggregate Turkish exports with 91 billion euros in 2018, reaching 47\% of her export revenues (see Table 9 in Appendix). Automotive (AU), Textiles (TE), Machinery (MW), Iron and Steel (IS), and Chemicals (CH) sectors have emerged as the most exporting sectors to the world. The share of the EU28 market in the total exports of these sectors is $78 \%$ for Automotive, $60 \%$ for Textiles, $57 \%$ for Machinery, $44 \%$ for Iron and Steel, and $43 \%$ for Chemicals in 2018.

The Customs Union agreement that was initiated in 1996 had been particularly conducive to expanding bilateral trade relations with the EU. Over the years, the two economic bodies have dwelled in wide-reaching partnerships in trade and joint ventures. Following the European Commission's declaration of the EGD at the end of 2019, it is predicted that the attitudes of the countries on climate issues will affect their bargaining power in the negotiations to be held with the EU on issues such as the ongoing Custom Union Modernization negotiations (PMR, 2018, p. 50). Besides, the effects of the contraction experienced during the COVID-19 pandemic in the global economy are expected to be extremely severe for developing countries like Turkey, whose economies are highly reliant on external markets. Turkey's steps to be taken both in the private sector, as well as public awareness on the climate facade, will support a sustained trade market share in the international arena as well as a greater share of the globally expanding green finance.

Given this historical background, it is clear that the EU's call for the EGD will generate very strong repercussions on the Turkish industry, as well as its trade relations at large. Considering that the EGD is effectively a response to the current issues regarding climate change, delineating a new strategy for growth to make the EU a fairer and more prosperous society (European Commission, 2019), major trade partners such as Turkey will be affected by the policies that are to be introduced within the context of the EGD. Current policies implemented in Turkey, unless reconsidered and aligned with the EGD, have the potential to bear significant costs in the case of a possible CBA and in a world where circular economy principles rule international trade. Market share loss in addition to export revenue loss along with the tax burden of a CBA mechanism would proliferate these costs. Besides, the cost of non-compliance with the EGD might increase substantially with the political conflicts that cannot be modeled but are highly probable.

\section{Materials and methods}

\subsection{The input-output model and data sources}

Our "base-year" is 2018, given the most recent available greenhouse emissions inventory and the heart of our data set is the 2012 input-output (I-O) data released by TurkStat. We first aggregated the 65 sectors of the original 2012 I-O table to 24 model sectors. To increase the relevance of the study by employing the most recent data (sectoral exports and GHGs emissions), we updated the I-O table to 2018 by using the standard RAS method. The RAS method is a well-known method for data reconciliation that aims to achieve consistency between the entries of some nonnegative matrix and pre-specified row (total use 


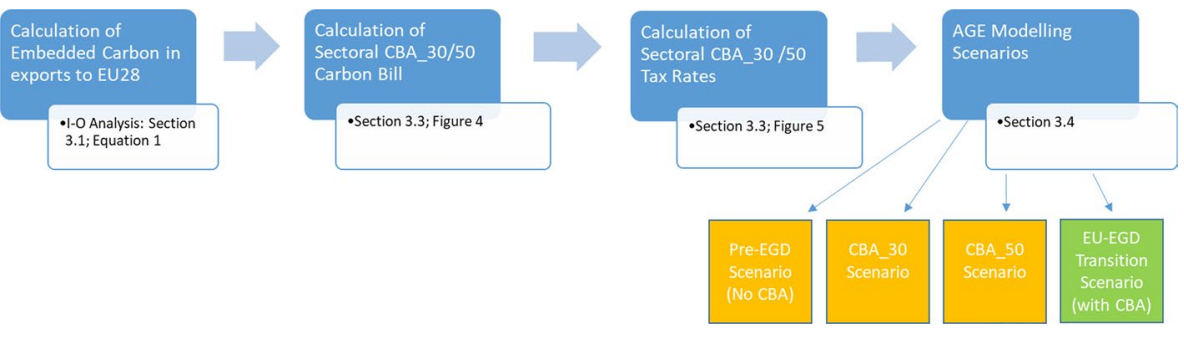

Fig. 2 Research framework

in I-O jargon) and column totals (total output in I-O jargon) (United Nations, 1993). This consistent data set is then utilized to "calibrate" the micro/sectoral and macroeconomic balances of the analytical model to the existing data. The 2018 I/O Table is disclosed in Appendix. Figure 2 summarizes the methodology followed.

In 2018, Turkey emitted a total of $520.9 \mathrm{Mt} \mathrm{CO}_{2} \mathrm{e}$ of $\mathrm{GHG}$ emissions to the atmosphere. This sum is grouped by the GHG Inventory under energy combustion (321.2 Mt), industrial and agricultural processes (130.0 Mt), and household waste (69.6 Mt). After leaving aside the household waste, we allocate the remaining 451.3 Mt of GHGs emissions to the 24 sectors by making use of the TurkStat data as reported to the UNFCCC inventory system. The original data on greenhouse gas source and sink categories are used whenever it was possible to make a direct connection between the sectors recognized in the official data and our aggregation distinguished in the model. ${ }^{2}$ Following Acar and Yeldan (2016), we allocated the remaining unaccounted $\mathrm{CO}_{2} \mathrm{e}$ emissions using the share of sectoral intermediate input demand to the aggregate volume of sectoral output as weights. Sectoral GHGs allocation is shown in Table 7 in Appendix.

\subsection{Emissions embodied in Turkey's exports to the eu28 market}

In the second step, we conduct an input-output analysis to calculate the sectoral emissions embodied in the exports to the EU28 market to analyze the potential effects of the CBA on Turkish sectors exporting to the EU market (see Table 9 for sectoral exports to the EU market in 2018). The GHGs emissions embodied in the EU28 exports are calculated using Eq. 1:

$$
\mathrm{GHG}=K_{\mathrm{GHG}}(I-A)^{-1} \mathrm{EX}_{\mathrm{EU} 28}
$$

where $E X_{E U 28}$ is the diagonalized vector of exports to the EU28 market, $(I-A)^{-1}$ is the Leontief inverse, $K_{G H G}$ is the diagonalized GHG-intensity vector, ${ }^{3}$ and $G H G$ is the $24 * 24$ matrix of GHGs embodied in EU28 exports. The row sums of the GHG matrix give the total GHGs embodied in the exports of the corresponding column sector. The I-O analysis makes it possible to decompose emissions over different scopes. The diagonal elements of

\footnotetext{
${ }^{2}$ Direct sectoral emissions data were available for Agriculture, Mining, Food Processing, Paper Products, Refined Petroleum, Chemicals, Cement, Iron \& Steel, Transportation, and Electricity.

3 The GHG-intensity vector shows the amount of sectoral tons of GHGs per million TL sectoral total output (taken from the $2018 \mathrm{I}-\mathrm{O}$ table of Turkey) and is reported in Appendix. It is similar to the employment/ value-added ratios that have been traditionally used in the I-O analysis. Note that sectoral imports are a part of the total sectoral output and are treated as complimentary or substitute to the domestic inputs.
} 


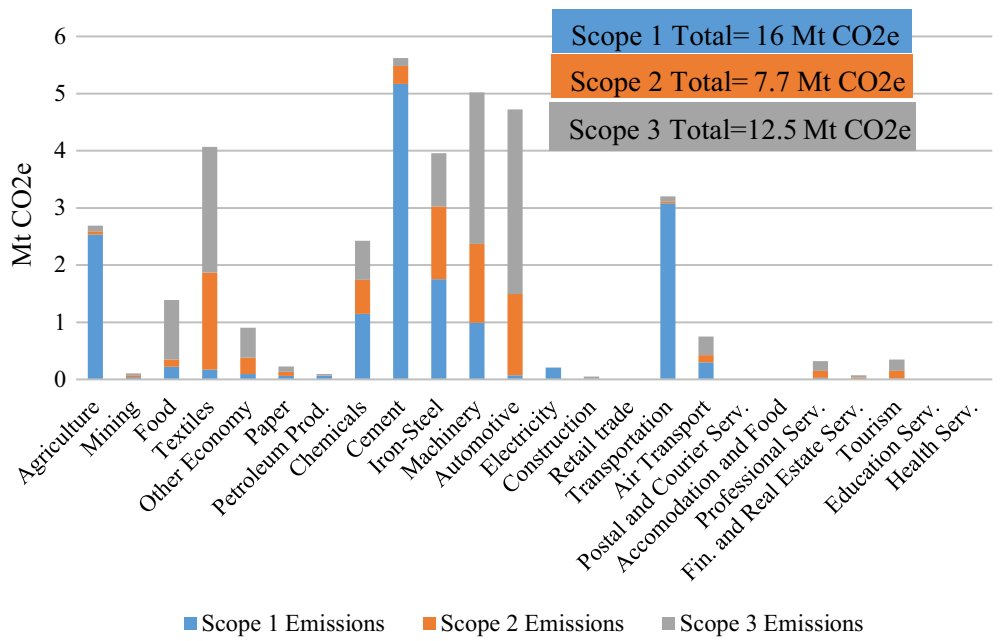

Fig. 3 GHGs emissions embodied in Turkish exports to EU28 (2018, Mt CO2e)

the GHG matrix show Scope 1, the electricity row elements show Scope 2, and the sum of the rest of the column elements shows Scope 3 emissions embodied in exports to the EU28 market.

Note that it is still not clear how the CBA will be implemented regarding the scope of emissions ${ }^{4}$ and sectoral coverage. Currently, under the ETS mechanism, the EU prices the Scope 1 emissions of intra-EU plants/power stations under the seven energy- and carbonintensive sectors listed in Table 7 in Appendix. However, covering only the Scope 1 emissions of a limited number of sectors does not necessarily mean leaving the majority of emissions outside the ETS. Note that pricing Scope 1 emissions in the ETS-covered sectors increases not only the production costs directly but also the costs of other sectors using them as inputs in their production processes. For example, the Textiles sector $(C 13-C 15)$ does not pay for its emissions since it is not currently covered under the EU ETS. Yet, it faces higher costs for its inputs such as electricity and chemical inputs as these are covered under the ETS. Once electricity or chemical input providers reflect the carbon price on their prices, the unit costs of a textile plant will also increase. This is similar to the case when a textile plant is required to pay for its Scope 2 and (part of) Scope 3 emissions. Taking into account the fact that one of the main aims of the CBA mechanism is to level the cost disadvantages of intra-EU producers caused by carbon taxation vis-a-vis producers outside the EU (with no or weaker carbon regulation), this will necessarily require the CBA to consider not only Scope 1 emissions but also Scope 2 and Scope 3 emissions (see Marcu et al. (2020) for a detailed discussion).

Thereby, we proceed with two further working hypotheses: Firstly, unlike the implementation under EU ETS, we assume that the CBA will cover all three scopes of emissions

\footnotetext{
4 The emissions of the plants are grouped under three sections. Scope 1 is direct emissions generated by owned or controlled sources; Scope 2 emissions are indirect emissions from the generation of purchased energy; and Scope 3 emissions are indirect emissions from the production of other purchased inputs (WRI and WBCSD, 2004).
} 


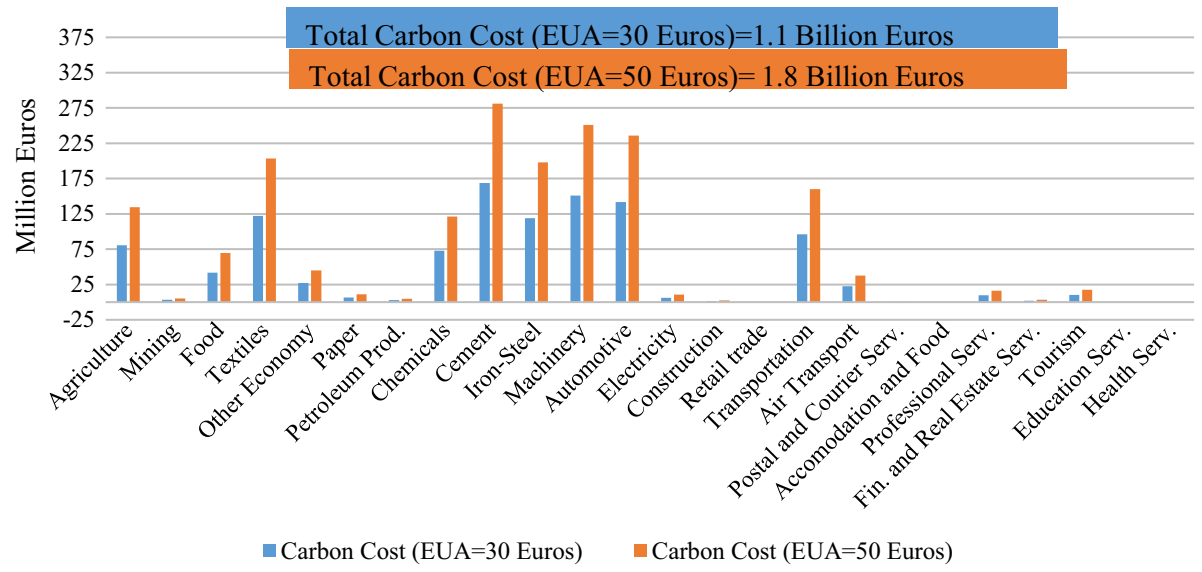

Fig. 4 Carbon costs (million euros)

embodied in the goods exported to the EU market, and secondly, we assume that exports from all sectors to the EU market (not only ETS-covered sectors' exports) will be subject to the CBA.

The I-O analysis makes it possible to decompose GHGs over different emission scopes. The diagonal elements of GHG represent the sectors' Scope 1 emissions embodied in exports, and the elements of the electricity (EL) row represent the sectors' Scope 2 emissions related to the use of electricity input. The rest of the elements show the Scope 3 emissions of the column sector related to the use of corresponding inputs purchased from the row sector. The decomposition of the sectoral emissions is given in Fig. 3.

Turkish exports to the EU28 market in 2018 contained $36.2 \mathrm{Mt}$ of $\mathrm{CO}_{2} \mathrm{e}$ emissions (Scope 1-2-3), and the majority of them were concentrated in Cement (CE), Machinery (MW), Automotive (AU), Iron and Steel (IS), and Textiles (TE) sectors.

\subsection{Calculating the CBA-induced carbon cost}

The CBA-induced carbon cost is calculated simply by multiplying the carbon embodied in exports with a unit carbon price of 30 and 50 euros/ton $\mathrm{CO}_{2} \mathrm{e}$. At the time this study was initiated (at the beginning of 2021), carbon prices in the EU ETS market were fluctuating around 30 euros per ton. At the beginning of May 2021, the unit carbon cost (i.e., EU allowance (EUA)) hit 50 euros a ton, being the highest since the carbon market was launched in 2005. Alberici et al. (2014) estimate that 50 euros/ton is a central value of the climate cost of $\mathrm{CO}_{2}$ emissions. OECD (2021) also uses very close unit cost values to the ones chosen in this study as carbon price benchmarks. Thirty euros/ton is taken as a historic low-end price benchmark of carbon costs in the early and mid-2010s and 60 euros/ton is chosen as a low-end 2030 and mid-range 2020 benchmark by the OECD (2021).

Figure 4 shows that if the Turkish exporters were required to pay 30 euros per ton of GHGs (all scopes), they would have faced a carbon cost of 1.1 billion euros (1.8 billion euros if the price of EUA were to be 50 euros). Yet, carbon costs may not fully quantify the level of vulnerability (which can be defined as the export revenue fall risk) to the CBA. Dividing sectoral carbon costs to exports revenues earned from the EU28 


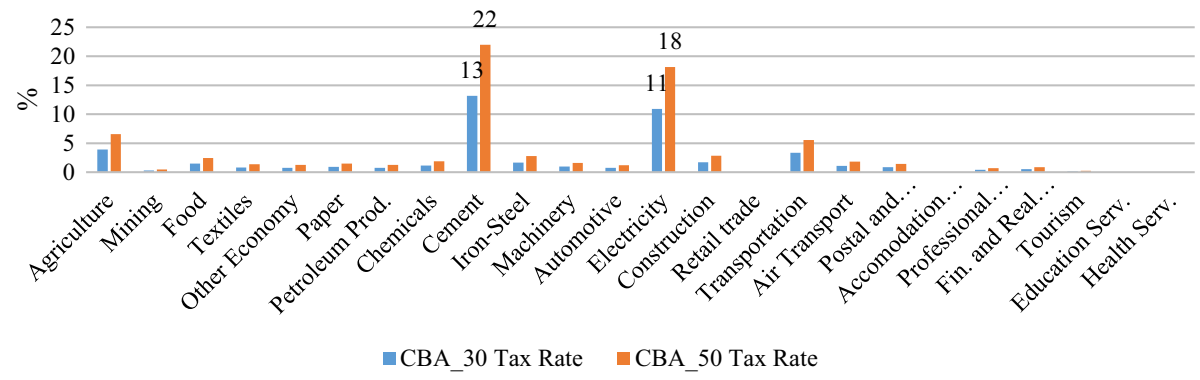

Fig. 5 CBA tax rates

market would give a much clearer picture. In terms of the sectoral "shadow" tax rates (CBA_30/CBA_50 when the EUA price is 30/50 euros), one can see that the CBA would have the worst impact on the "Cement" and "Electricity" sectors in Turkey. Figure 5 shows that GHG-intensive cement and electricity exporters to the EU28 market should pay back, respectively, 22 and 18 euros per 100 euros of the earned revenues to the EU ETS (see Table 9 in Appendix).

\subsection{General equilibrium analysis of alternative pathways}

Now we turn our focus to dynamics and setting alternative pathways. To this end, we will make use of an applied general equilibrium model constructed for the Turkish economy. The model is in the Walrasian tradition wherein aggregate supply and demand actions are simulated with the interplay of relative prices to bring equilibrium in the commodity markets (including the real wage rate and the real exchange rate to clear the labor and the forex markets, respectively).

The model is constructed around 24 production sectors, which is a direct aggregation of the (most recent) 2012 official input-output database supplied by TurkStat. It accommodates capital and labor as factor markets, a government entity to maintain taxation and public expenditures, as well as administration of environmental policy instruments, and the rest of the world account to carry out foreign transactions.

Given the base-year (2018) data tabulated within a social accounting framework, we first utilize the algebraic specification of the AGE to find numerical values of various structural parameters embedded in the model (calibration). Then, we solve the model into the future under the assumption of no changes in the business environment, nor alterations of the policy stance. This, to be referred as the business-as-usual (BaU) path, is by no means a "projection" but is only an artificial artifact to serve solely for purposes of testing the economic performance of the alternative policy environments as to be resolved by the model.

\subsubsection{Algebraic structure of the AGE model and the database}

Emissions: Greenhouse gas emissions are modeled through three main channels: (i) from energy utilization (via combustion of primary - coal, petroleum, and gas, and 
secondary-refined petroleum) sources; (ii) from industrial and agricultural processes in production; and (iii) form household consumption and waste. Emissions from primary energy combustion activities are set proportional to intermediate inputs of coal and petroleum and gas:

$$
\mathrm{CO} 2_{\mathrm{ji}}=\varepsilon_{\mathrm{ji}} a_{\mathrm{ji}} X_{\mathrm{i}}^{\mathrm{S}}
$$

where $C O 2_{j i}$ denotes emissions originating in sector-i due to utilization of input-j (=coal, crude petroleum, and gas) and $\varepsilon j i$ narrates the intensity of this process due to utilization of the input-j per unit $\left(a_{j i}\right)$ of output produced in sector-i $\left(X_{i}^{S}\right)$. For the secondary sources of energy combustion, we set $\mathrm{j}=$ Refined Petroleum. Industrial/agricultural processes are taken proportional to the relevant sectoral activity via

$$
\mathrm{CO} 2_{\mathrm{ji}}^{\mathrm{IND}}=\eta_{\mathrm{i}} X_{\mathrm{i}}^{\mathrm{S}} \text {. }
$$

In turn, households' demand for energy and consequent emissions are regarded as proportional to sectoral consumption:

$$
\mathrm{CO} 2^{\mathrm{HH}}=\Sigma_{\mathrm{ki}} C_{\mathrm{i}}^{\mathrm{D}}
$$

\subsection{Production technology and factor markets}

Production activity in each sector uses capital, labor, energy, and intermediate inputs. To obtain the highest possible response of substitutability, the algebraic form of the production activities accommodates a nested structure wherein at the top of the stage, gross output is given by an expanded Cobb-Douglas specification via,

$$
X_{\mathrm{i}}^{\mathrm{S} .}=\operatorname{cd}\left(A_{\mathrm{i}}, K_{\mathrm{i}}, L_{\mathrm{i}}, E_{\mathrm{i}}, N_{\mathrm{i}}\right)
$$

with $K_{i}$ and $L_{i}$ representing, respectively, the capital and labor factors; $N_{i}$ standing for the flow of intermediates (except for the primary and secondary sources of energy inputs recognized above) $\left(\sum a_{j i} X_{i}^{S}\right)$; and $A_{i}$ capturing the index of Hicks-neutral sectoral total factor productivity (TFP). $E_{i}$ stands for an aggregate composite energy input in sector-i and is obtained by a constant elasticity of substitution (CES) function among coal, petroleum, and gas, and electricity as inputs,

$$
E_{\mathrm{i}}=\operatorname{ces}\left(N_{\mathrm{coal}, \mathrm{i}}, N_{\mathrm{PET}, \mathrm{i}}, N_{\mathrm{GAS}, \mathrm{i}}, N_{\mathrm{ELC}, \mathrm{i}}\right)^{\mathrm{s}}
$$

with $\sigma$ allowing for the constant (yet, less than infinitely perfect) substitution elasticity among the relevant energy inputs.

Such a specification in the production sphere allows for the full potential of technological substitution in response to relative prices and abatement instruments. Factor markets are assumed to clear through flexible rental and wage rates, as we prefer to abstain from issues of factor market rigidities and structural characteristics of the labor markets. 


\subsection{Income generation and aggregate demand}

Private sector is represented as one aggregate household. The household budget comprises returns from factor payments, remittances of the corporate sector, and net foreign flows. The household further pays taxes, receives social transfers, and earns interest income on its holdings of public debt. The public sector's main source of income is tax revenues, implemented in various forms-indirect production and consumption taxes, direct household and enterprise taxes, and various levies on imports. Given social transfers and public expenditures as policy instruments (set to the level of GDP), the resulting Public Sector Borrowing Requirement (PSBR) is covered by issuing debt instruments. In the absence of full accommodation money and financial markets, we set the (real) interest rate on these instruments exogenous.

Private consumption expenditures are allocated across sectors given relative prices with the assumption of a Cobb-Douglas type of preference maximization in the background. Saving propensities set private savings, and under neoclassical closure, investment expenditures are directed to capital accumulation and net of depreciation.

Following the common AGE folklore, the model relies on the hypothesis of import substitution in trade (Armingtonian composite good system a la Armington, 1969). This specification is known to allow for more flexibility in the domestic price system, in contrast to traditional open-economy trade models where the law of one-price rules (hypothetically convenient, yet unavoidably unrealistic at this level of aggregation).

\subsection{Equilibrium}

The overall model is brought into equilibrium through endogenous adjustments of product prices to clear the commodity markets and factor prices to clear the factor accounts. The balance of payments is cleared through flexible adjustments of the real exchange rate (defined, in the auspices of our model specification as the ratio of the index of domestic good prices to that of import costs). The "nominal" exchange rate (the conversion factor) across domestic and foreign prices), in contrast, is exogenously set as the numéraire of the system.

\subsection{Dynamics}

"Dynamics" into the model is integrated via sequentially updating of the annual "solutions" of the model up to 2030. Economic growth is the end result of (i) exogenous growth of labor supplies; (ii) investments on physical capital stocks net of depreciation allowances; and (iii) total factor productivity (TFP) growth. Technical factor productivity rates are updated in a Hicks-neutral manner and further by parametric adjustments under the implementation of the policy scenarios.

\subsubsection{Policy analysis}

Given the Paris 2015 parlance, a significant task of our narration rests on the specification of the official INDC pathway. Turkey's INDC had been set as targeting a $21 \%$ reduction over the officially set base path, and its (lack of) realism had been the subject of significant controversy. 
The most recent official document specifying Turkey's national emission reduction targets is the INDC submitted to UNFCCC on September 30, 2015, just before the COP 21 meeting held in Paris. ${ }^{5}$ The document summarizes the national criteria to be applied by Turkey, with an emphasis on the special requirements applicable to the country and notes how the emission reduction and compliance strategies were to be established. The document specifies the time frame 2012-2030 as its implementation window and entails a declaration on part of Turkey, for a $21 \%$ reduction of its greenhouse gas emissions, from 1,175 million tons of $\mathrm{CO}_{2}$ equivalent $\left(\mathrm{CO}_{2} \mathrm{e}\right)$ as envisaged in the business-as-usual (BAU) scenario, to 929 million tons of $\mathrm{CO}_{2} \mathrm{e}$. It is noted that doing so would constitute a major step toward low-carbon development, to achieve the goal of keeping warming under $2^{\circ} \mathrm{C}$ at a global scale. The INDC also entails references to certain plans and policies envisaged for emission-intensive industries. However, the INDC does not provide specific figures for individual industries' emission reduction over BAU levels in the period 2021-2030, to be achieved through such policies and measures.

\subsubsection{Facing the European green deal}

We now use our model to analyze the effects of the possible threat of the border adjustment tax implementation on the Turkish economy, along with a quest toward transforming the domestic economy toward the EU's greening standards. The model results will allow us to evaluate the costs and benefits of alternative policy environments including macroeconomic aggregates, sectoral production, and employment, technological change, as well as pathways of gaseous emissions.

With the aid of the model, we simulate three alternative policy environments, along with a hypothetical historically determined base path:

- $C B A \_30$ scenario simulates the macroeconomic environment under the working hypothesis that Turkey invokes no change in its current climate policy stance, and faces a levy of euro 30/ton $\mathrm{CO}_{2} e$ in her exports to the EU, given the sectoral $\mathrm{CO} 2(\mathrm{eq})$ intensities of exportables.

- CBA_50 scenario repeats the above scenario under the assumption that Turkey faces the upper-end of the levy, at euro 50/ton $\mathrm{CO}_{2}$ e.

- EU-EGD transition scenario simulates an alternative pathway through which Turkey is modeled as an active agent in the international arena, embedding decarbonization into her official macroeconomic policy agenda.

Components of this "green policy agenda" are further envisaged as follows:

Pricing of carbon, together with the implementation of an administrative mechanism to enact a carbon-trading market a la ETS of the EU: Here, we instruct the agents with a binding constraint of a $21 \%$ reduction in $\mathrm{CO}_{2} \mathrm{e}$ emissions over the base path (to be narrated below) by 2030. In the pragmatic implementation of this target, we have taken our model's historical base-path solution as the relevant reference point in action and relied on the Walrasian apparatus to obtain a (shadow) price for the imposition of the carbon quota.

\footnotetext{
5 Intended Nationally Determined Contributions for the Republic of Turkey. https://www4.unfccc.int/sites/ submissions/INDC/Published\%20Documents/Turkey/1/The_INDC_of_TURKEY_v.15.19.30.pdf.
} 
Constrained by the $21 \%$ reduction, the simulated working of the "carbon market" generates a premium for those who met the quota to "sell" the emission rights to those who had not. In other words, the binding quota will require the "purchase" of $\mathrm{CO} 2$ emission rights and thus becomes a cost factor. Under this system, emission permits will have a market value and be traded. Resolution of the market equilibrium leads to a price for carbon emission rights.

Technological change: We administer the budgetary consequences of this operation by re-directing the aggregate quota rents to the enterprises which had participated in the carbon-trading market. This specification mocks the workings of the ETS as institutionalized in the EU and is expected to serve as a source of innovation and technical change for furthering the green development cause. This "investment fund" is thought to stimulate further technological productivity improvements at the industry level, and a modest additional gain of 1 percent is added to the total factor productivity (TFP) advances of the industrial sectors.

International finance: On the geopolitical front, we envisage that, together with signing the 2015 Paris Agreement and taking an active role within the green new deal community, Turkey will be able to attract an increased share of the global green finance funds.

Historical evidence reveals that the global climate funds have been evolving over three main sources-bilateral versus multilateral public climate finance across institutions and through export credits (mainly over renewable energy outlets) (Helm \& Schmidt, 2015; OECD, 2019). OECD (2019) reports, for instance, that climate funds mobilized by the developed countries stood at only US\$58.6 billion and is estimated to increase at an average rate of $21 \%$ since then. CPI (2019) also documents that Turkey's share in these funds had been on the order of US\$8 billion over 2015-2018. Projected over the medium run, the Institute of International Finance (IIF, 2019) reports further that the G-4 countries alone will be increasing their net public borrowing by more than threefold in 2020 and 2021 over 2019 to reach US\$ 5 trillion, and the volumes of the balance sheets of their respective central banks will likely to expand to US $\$ 22$ trillion by the end of 2020, in contrast to their total level of US\$15 tr in 2019.

It is clear that given the ongoing geopolitical premium over the green finance instruments reaching $15 \%$ (IIF, 2019), a significant portion of this expanding liquidity will likely be channeled to the ports of green activity. Thus, in what follows, we assume that through its efforts toward decarbonization and greening, Turkey will increase its international inflows at the rate of $0.5 \%$ of its GDP over our simulation pathway under the EU_EGD transition. Given the historical record that over the "normal" years of global finance Turkey had been the recipient of foreign flows at the rate of 9-10\% of her GDP, this assumption ought to be regarded as modest.

Base-path, business-as-(un)usual: As part of the tradition of applied modeling, we also implement a base-path scenario against which our scenario environments are contrasted. This is nothing more than a "reference" pathway, a-historical in nature, and serves only as a collection of checkpoints wherein our hypotheses are maintained over the dynamics of our model.

Over this path, we first introduce the projections of the exogenously specified flows and parameters. "Population" growth rate is adapted from the UN projections and TurkStat data and is set at $1.2 \%$ per annum. Capital stocks are updated by new (fixed) investments net of depreciation. Both the depreciation rate and sectoral total factor productivity (TFP) growth rates (growth rate of $\mathrm{A}$ in the production function above) are adjusted to obtain the projected growth of the domestic economy over 2015-2030, at the rate of $3.2 \%$ per annum. Detailed official growth projections are given for Turkey, albeit on a 


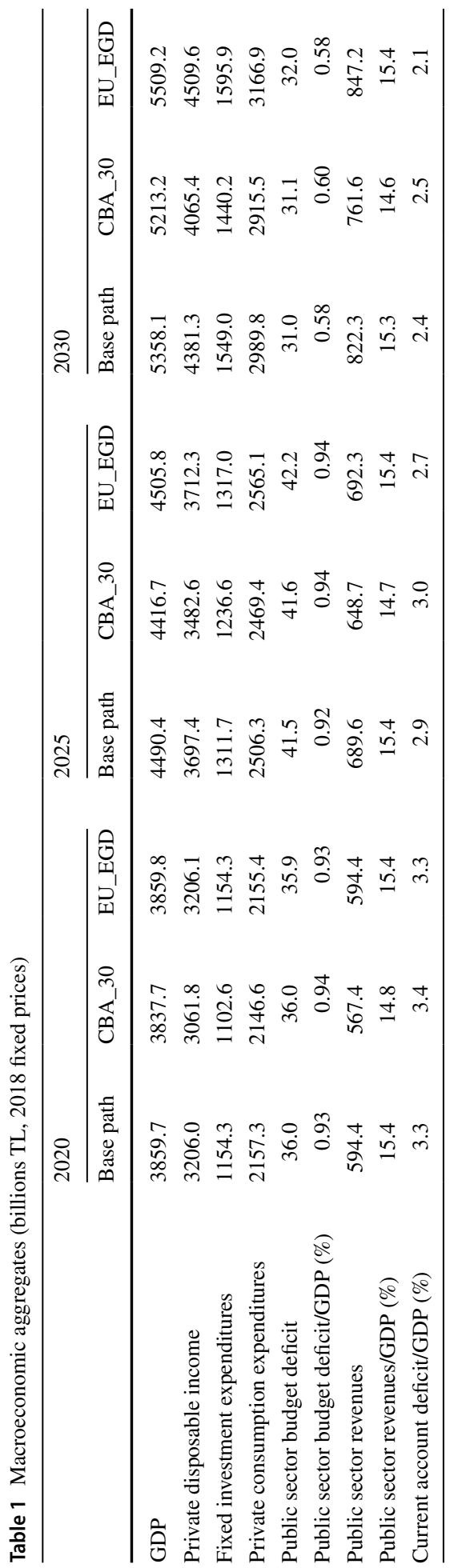




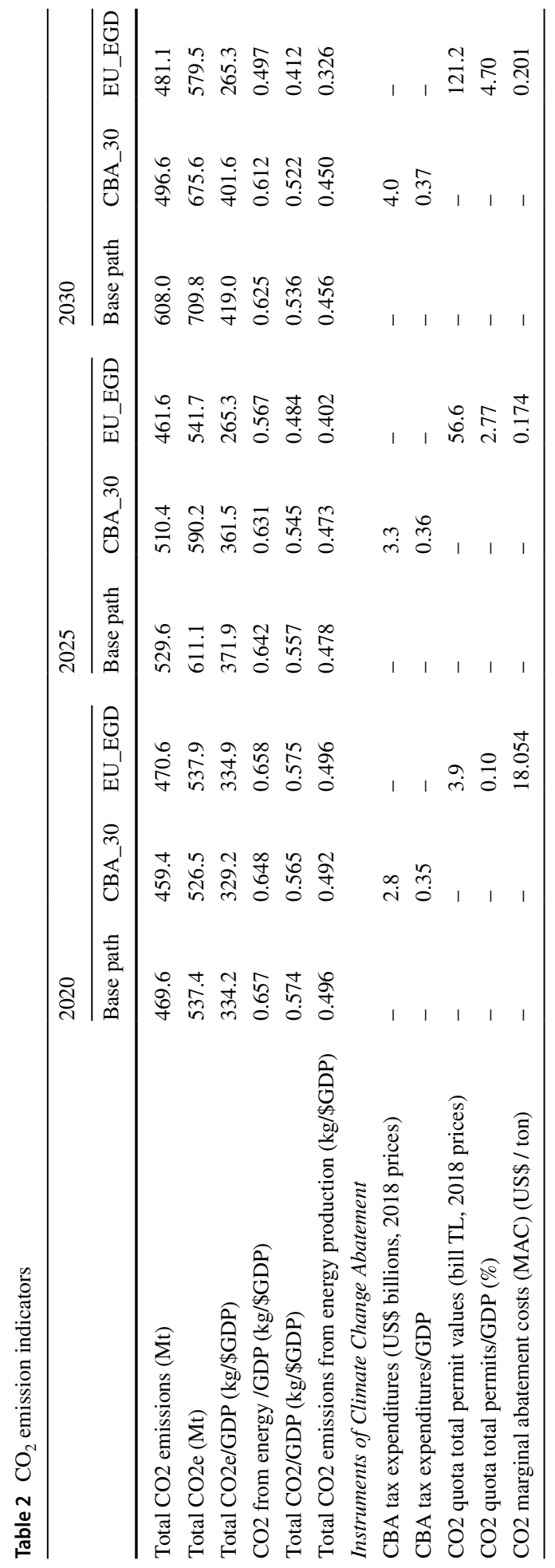




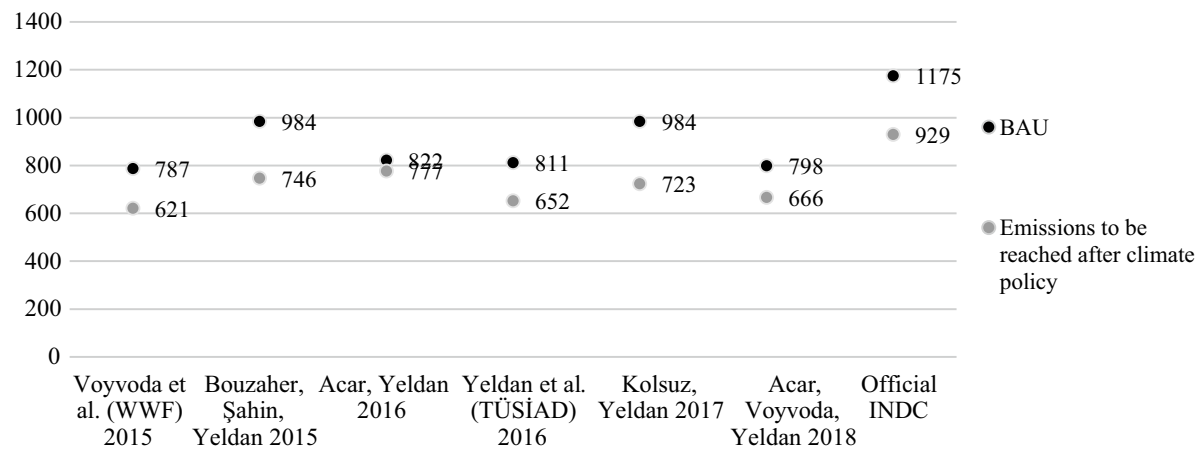

Fig. 6 Greenhouse gas emissions that could be reached by 2030 under various climate policy scenarios (Mt $\left.\mathrm{CO}_{2} \mathrm{e}\right)$. Source: Authors' compilation of the results from the relevant literature

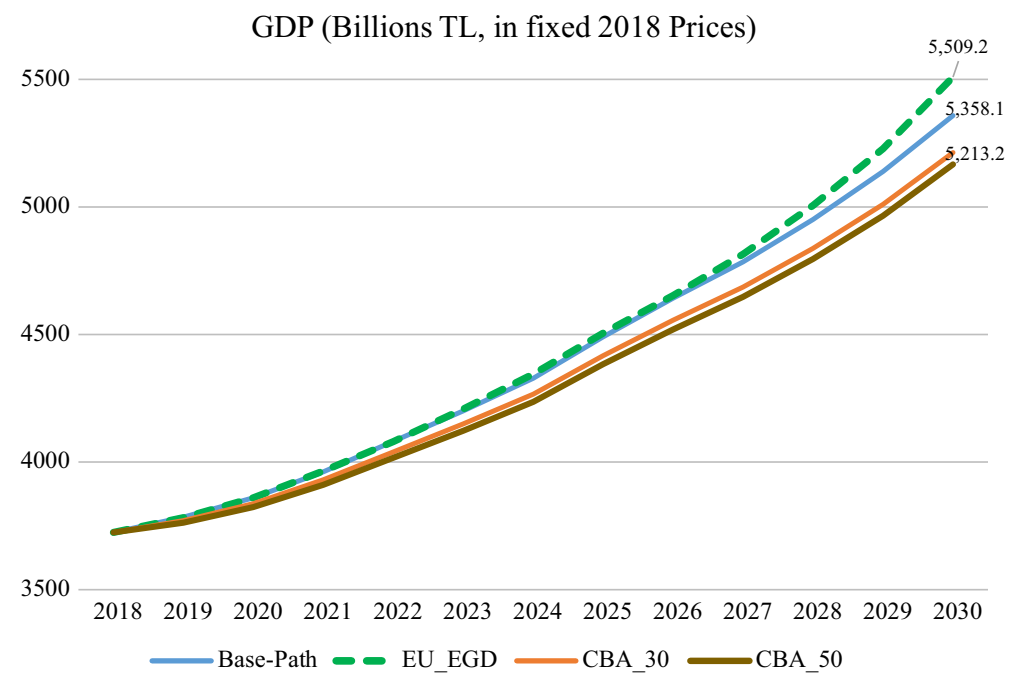

Fig. 7 The evolution of GDP (billions TL, in fixed 2018 prices)

very rough analytical backing, and for a short duration. The Medium-Term Program, for instance, follows a 5\% target in its macroeconomic projections over 2021-2022 (Ministry of Treasury and Finance TR, 2020). In contrast, OECD (2014) and IMF's World Economic Outlook (2020, April) projections suggest that the Turkish growth rates will likely be on the order of 3.0-3.5\% over the next decade.

Given this international evidence and data, we adopted the average annual growth target of $3.2 \%$ as our base-path rate over the 2019-2030 horizon. This assumption brings the aggregate real GDP to 2371 bn TL in 2030 (in fixed 2018 prices). Exogenous foreign flows are set at their historical ratios to GDP and were gradually reduced to yield a current account deficit of $2.5 \%$ by 2030 . The macroeconomic aggregates and emissions results of the base path and the scenarios are given in Tables 1 and 2. 
Total CO2 Emissions (million tons)

650

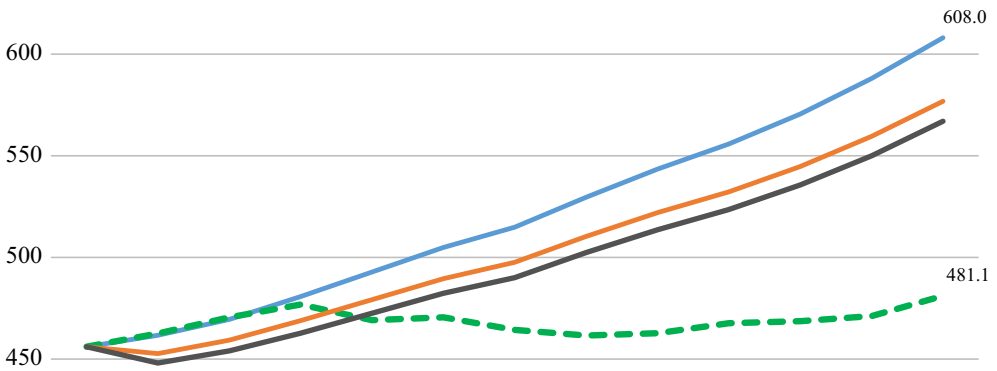

400

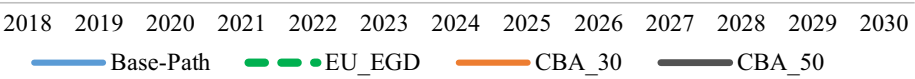

Fig. 8 The evolution of the total $\mathrm{CO} 2$ emissions (million tons)

\section{Results and discussion}

We calculate that given the base-path assumptions, Turkey will be responsible for a total of 709.8 Mt of gaseous emissions in the form of $\mathrm{CO}_{2} \mathrm{e}, 608 \mathrm{Mt}$ of which are $\mathrm{CO} 2$. This reflects an average annual rate of increase of $2.4 \%$ over our horizon. As a follow-up, we read that the carbon intensity of the domestic economy falls from $0.657 \mathrm{~kg} /$ GDP to $0.625 \mathrm{~kg} /$ SGDP under the base path. This is a natural reflection of our assumed rates of technical efficiency improvements under the projected historical trends (Fig. 6).

The implied pathways on national income and consequent gaseous emissions are portrayed in Figs. 7 and 8.

The border carbon adjustment taxation scenarios reveal that the loss of Turkey's GDP over the hypothetical base path is on the order of $2.7 \%$ to $3.6 \%$ by 2030 , depending on the size of the levy. But the more meaningful comparison is between the CBA scenarios and the green alternative of EU_EGD. Our simulation results indicate that Turkey's potential gains in her GDP will be on the order of 5.6\% (against CBA_30) and 6.6\% (against CBA_50). Private disposable income and private consumption (a conventional metric of private welfare in the AGE framework) will, respectively, be $10.9 \%$ and $8.6 \%$ higher under EU_EGD in contrast to CBA_30. A closer look at the macroeconomic aggregates also shows similar patterns. In comparison with the CBA_30, the green policy environment of EU_EGD displays an increase of $10.8 \%$ in fixed investments (calculated in fixed 2018 prices). Share of the budget deficit to GDP is followed to fall by 2.9 percentage points. This is due to the rise of government revenues by $11 \%$ under the EU_EGD policy environment due to more robust growth of the GDP growth.

With the effective implementation of the carbon quota, Turkey succeeds in lowering its total $\mathrm{CO}_{2}$ emissions to $481 \mathrm{Mt}$ by 2030 . This is achieved by reducing the carbon intensity of production to $0.49 \mathrm{~kg} / \$ \mathrm{GDP}$ from its above-mentioned level of $0.66 \mathrm{~kg} / \$ \mathrm{GDP}$ in 2018. Likewise, under the green scenario emission intensities in energy production fall from $0.496 \mathrm{~kg} /$ GDP to $0.326 \mathrm{~kg} /$ GDP in 2030 . The main economic instrument behind these achievements is the workings of the carbon-trading system. The model results suggest that 


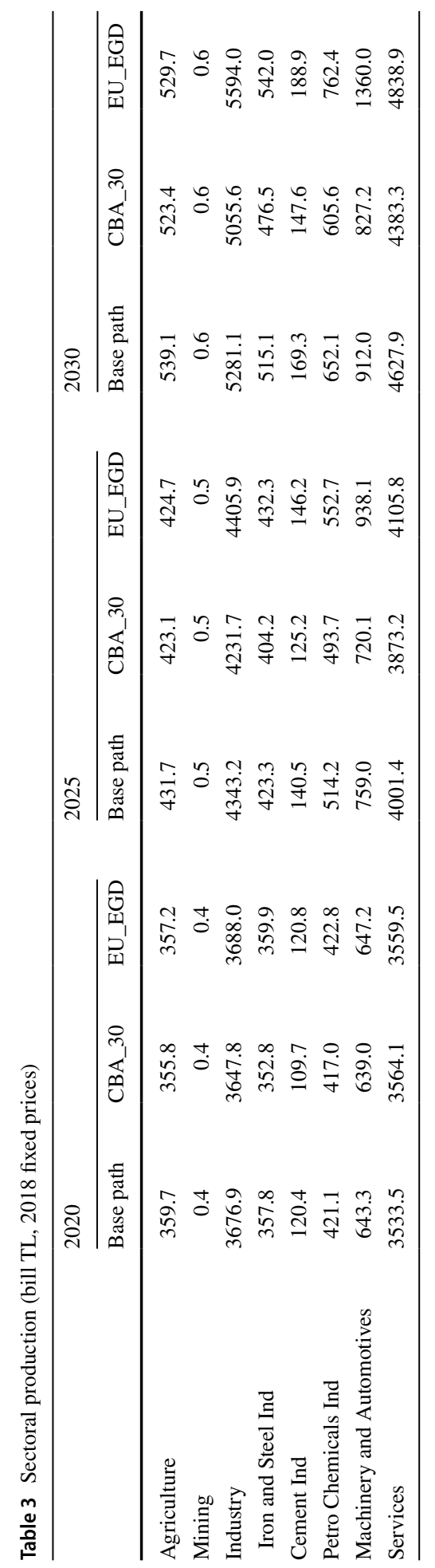




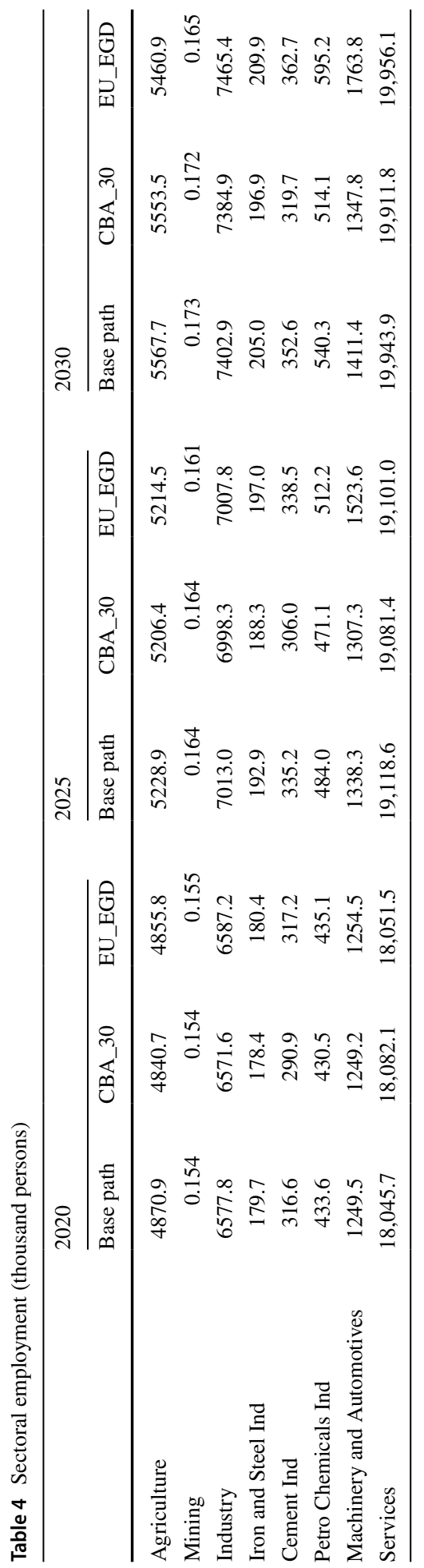




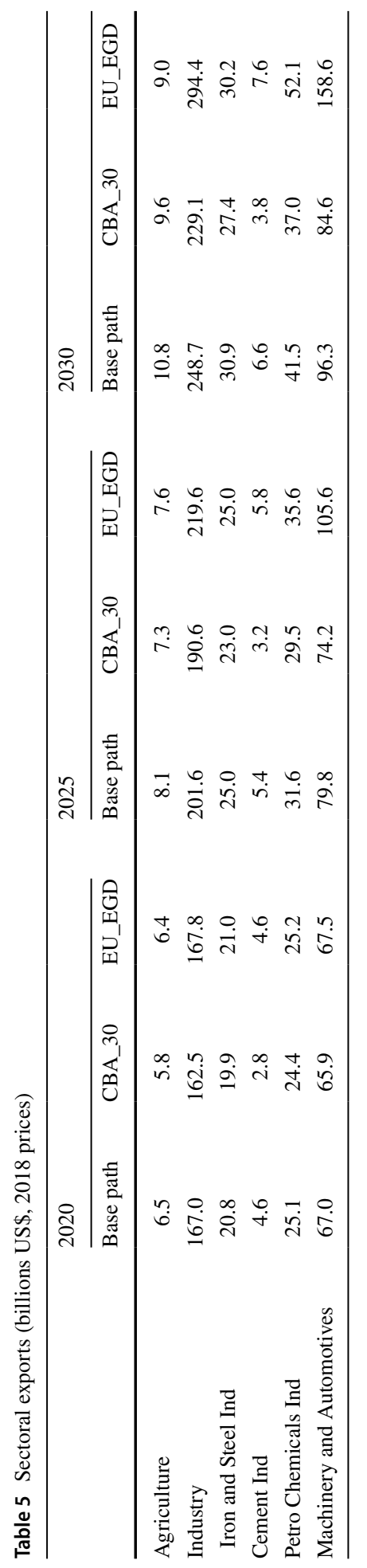




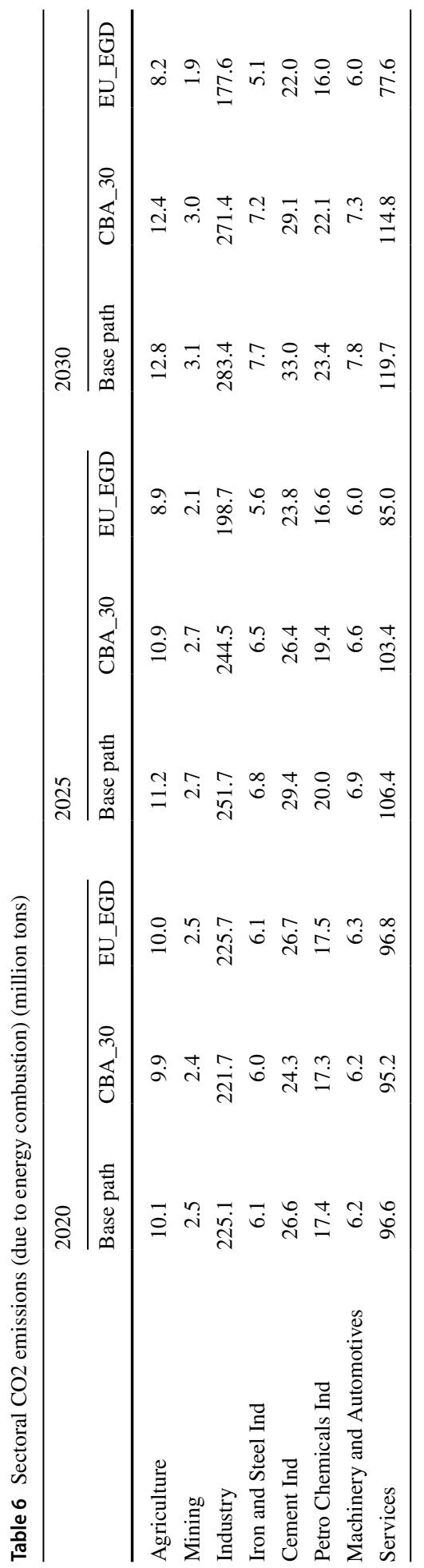


per ton of $\mathrm{CO}_{2} \mathrm{e}$ emissions, the (shadow) price varies around US\$26 to US\$53 over 2025 to 2030. The marginal abatement cost of the quota remains around 20 cents per ton of abatement by 2030 . As a ratio to GDP, the aggregate value of the quota premia (quota rents) reaches $2.1 \%$ in 2025 and $4.8 \%$ in 2030 . As discussed above, these monies are redistributed to the enterprise sector in the form of an investment fund for green transformation. This procedure prevents the carbon pricing mechanism from having an impact on public finances, or any other macroeconomic variable.

Sectoral results of our scenarios are displayed in Tables 3 through 6 . We read that, capitalizing over the induced efficiency gains, the industrial sectors expand along with a favorable impact on employment. Industrial production, in the aggregate, stands at $6.5 \%$ higher under the EGD environment in comparison with the no-change-in-action CBA_30 scenario. Gains are particularly strong in the exporting sectors such as Machinery and Automotive, where potential output gains exceed $60 \%$. In fact, given the prospects of a 30-euro/ ton levy, exports of these two sectors combined are threatened to fall by $13 \%$ against the hypothetical base path. In contrast, the EU_EGD policy setting reverses this threat to a potential opportunity with an expected rise of sectoral exports over $87 \%$ (Tables 4, 5, 6).

In sum, a green economic regime clearly improves private as well as social welfare. Furthermore, it has to be underlined that this conclusion does not include the positive externalities of improved health and environmental conditions originating from lowered gaseous emissions and enhanced environmental quality.

\section{Policy and managerial implications}

The CBA mechanism forces non-EU exporters belonging to a list of energy-intensive sectors to pay more attention to the GHG intensity of their production process. Moreover, the source of the electricity consumed (fossil or renewable) would also matter since the CBA mechanism includes Scope 2 emissions embedded in exports as well. CBAM is expected to increase the production costs both in the domestic economy and at the EU28 market and has the potential to alter the competitiveness of the exporting firms in the EU market. Acknowledging the extent of the CBA-related risks that exporters will face timely (before the CBAM takes into effect) is quite important to retain their competitiveness. The present study sheds light on these risks in a sectoral detail and helps policy-makers in identifying and prioritizing actions on a sectoral level.

The inclusion of the Scope 2 emissions to the CBA mechanism calls for a transformation of the Electricity sector which exceeds the sectors' financial capabilities. To avoid market failure, the government must step in by designing a general decarbonization program for electricity production in Turkey. In designing such a program, it is quite important 
to know the Scope 2-intensity of sectors as a measure of their transformation appetite. This study will help policy-makers in identifying the sectoral positions of the Turkish economy.

\section{Conclusion}

In this paper, we have sought to investigate the expected economic impacts of the European Green Deal policies on the Turkish economy and the potential benefits to be reaped by pursuing a more active climate policy. The EGD announced in December 2019 will affect the Turkish economy through two channels: the planned initiation of the carbon border adjustment (CBA) mechanism and the circular economy regulations. The current paper focuses exclusively on the effects of the CBA mechanism on Turkish exports to the EU market.

Our results suggest that the CBA may bring a carbon bill of 1.1-1.8 billion euros annually to the Turkish exporters in the EU market depending on the price of 30 and 50 euros per ton of GHGs. The Cement and the Electricity sectors are expected to be the worst affected. For every 100 euros of export revenues, the Cement and the Electricity sector should return 13-22 and 11-18 euros, respectively.

The EGD's potential adverse impact on the Turkish economy would range between $\% 2.7$ and \%3.6 loss of the GDP by 2030 over the business-as-(un)usual base path (pre2019 conditions). Note that this figure reflects only the effects of the CBA mechanism and not the costs associated with the Circular Economy regulations which will require Turkish exporters to redesign their product specifications.

Yet, our results also suggest that the risks can be turned into an opportunity by pursuing a more active climate policy and transforming the economic structure toward a more climate-friendly one. We find that under an alternative policy scenario wherein Turkey participates actively with (i) accommodation of a polluter-pays principle with an active carbon-trading market in which the price of $\mathrm{CO}_{2}$ is determined in lieu of a binding carbon quota (set at the official INDC target of Turkey at $21 \%$ reduction over the baseline); (ii) allocation of permit-rent revenues to the enterprises directly in exchange for efficiency improving investments; and (iii) provision of increased efficiency gains in electricity generation and dissemination, Turkey can achieve a superior pathway for national income and reduced carbon burden, with increased household and enterprise net incomes.

The revision of the INDC target and the ratification of the Paris Climate Agreement at the parliament are two steps that can be taken immediately. Speeding up the ongoing preparatory process of instituting an emission trading system in Turkey (preferably linked to EU ETS) will help minimize economic losses. Overall, a shift to an active climate policy will help Turkey to access climate finance opportunities which will ease the climatefriendly transformation of Turkish sectors. 


\section{Appendix}

\section{Data and the calibration methodology}

The micro-level I-O data are expanded into a social accounting matrix (available from authors upon request) given the aggregate macro-data on public sector balances and resolution of the saving-investment equilibrium.

Turkey's GDP was recorded at 3,724 billion TL (789.1 bn US\$). The private savings ratio stood at 27.4\% (Medium-Term Economic Program-MTEP data). Given private savings and the size of total public expenditures at 552.8 bn TL (14.8\% of GDP), we calculated the public savings-investment gap as 72.8 bn TL and set it to the PSBR (1.9\% to the GDP) to close the private and public sector accounts. Domestic debt stock stood at 1,132.2 bn TL (30.4\% as a ratio to GDP) as of 2018 .

The resolution of the aggregate savings-investment balance yields the current account balance at $-72,800$ million US\$, 3.4\% of the GDP. The average rate of foreign exchange is taken as $4.72 \mathrm{TL} / \mathrm{US} \$$, and the rates of foreign and domestic interest rates are set at $2 \%$ and $5 \%$, respectively.

Labor market data are tabulated from the TurkStat Household Labor Force Surveys. 2018 data reveal that total employment stands at 28,738 thousand persons. Sectoral distribution of this sum had been achieved using the TurkStat data implementing our sectoral aggregation of the original $\mathrm{I}-\mathrm{O}$ data. Total wage costs are observed to reach $1,223.8$ bn TL or $32.9 \%$ of the GDP. The economy-wide annual average wage rate is thereby calculated to be $42,586 \mathrm{TL}$ (US\$ 9,022.1). Appendix Table 10 further documents the labor market data across sectors.

See Tables 7, 8, 9, and 10 . 


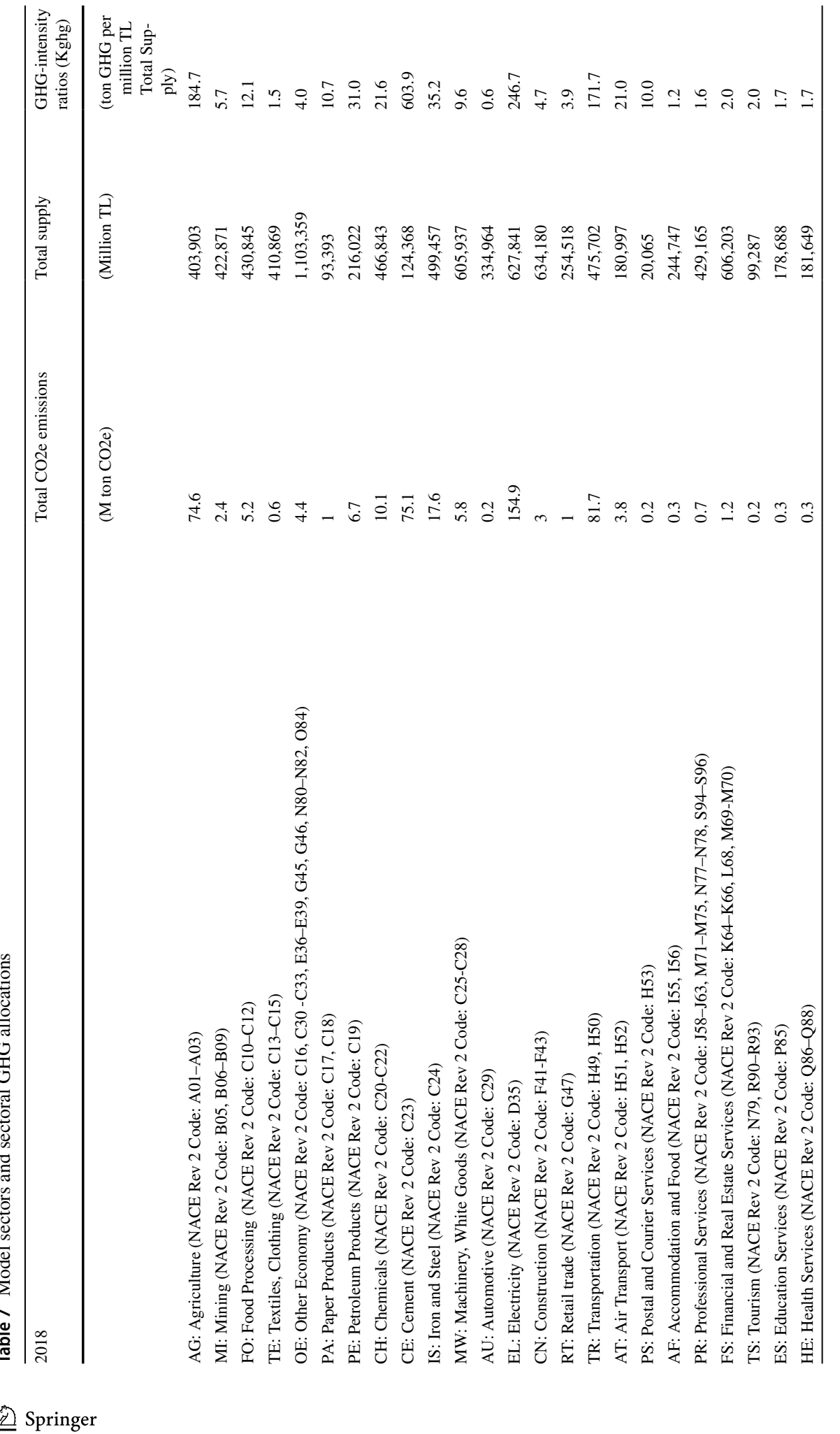




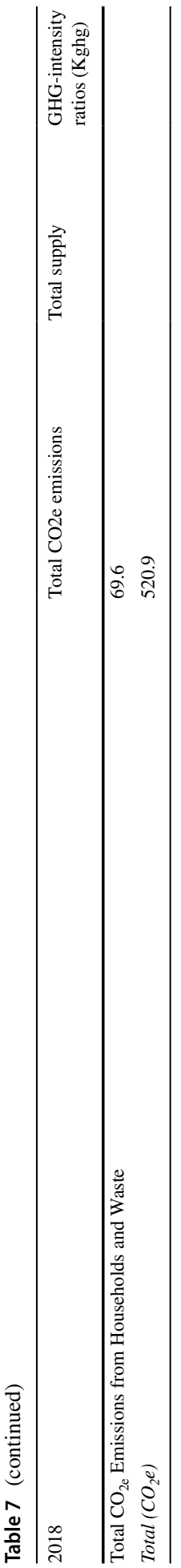




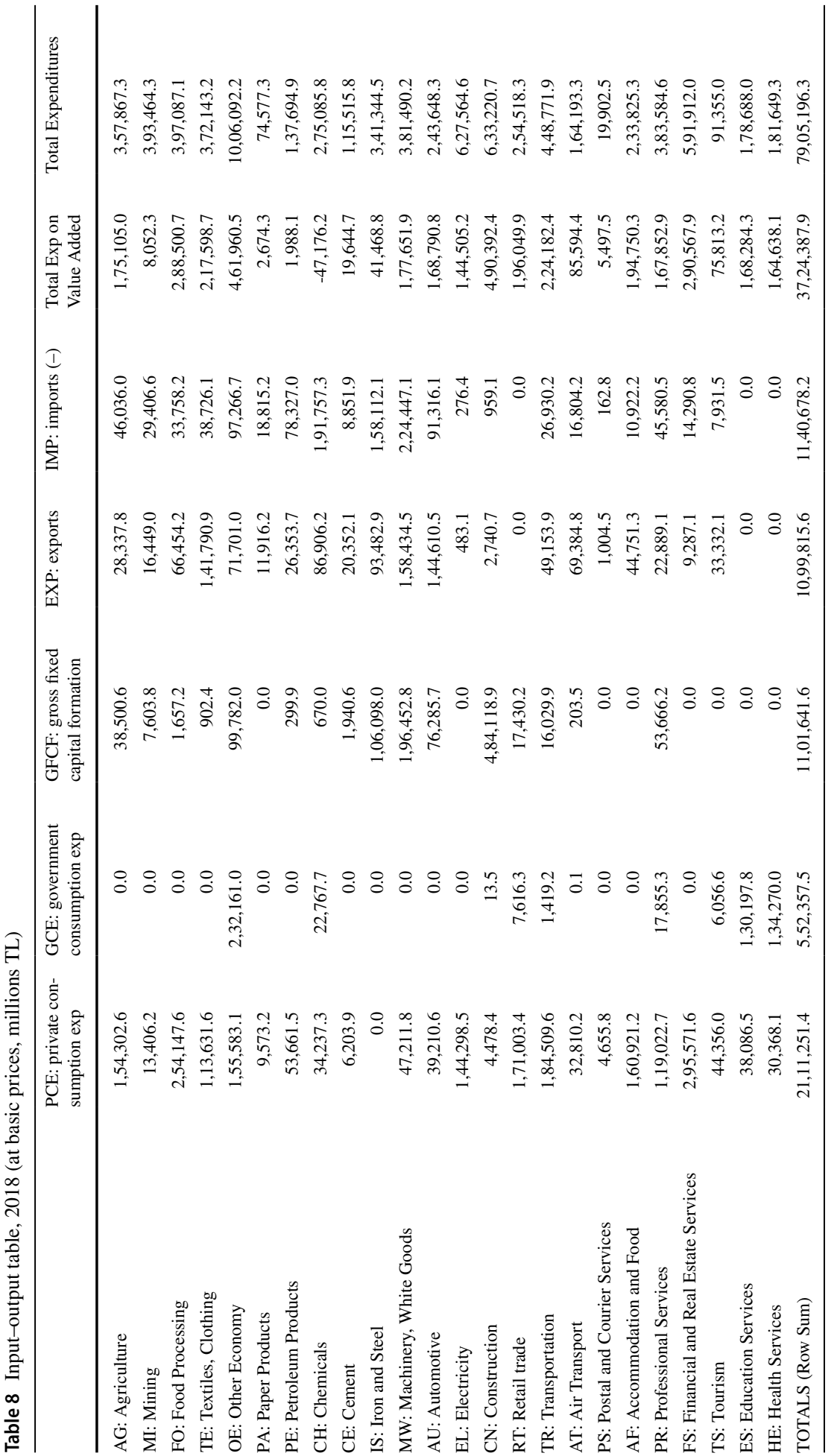




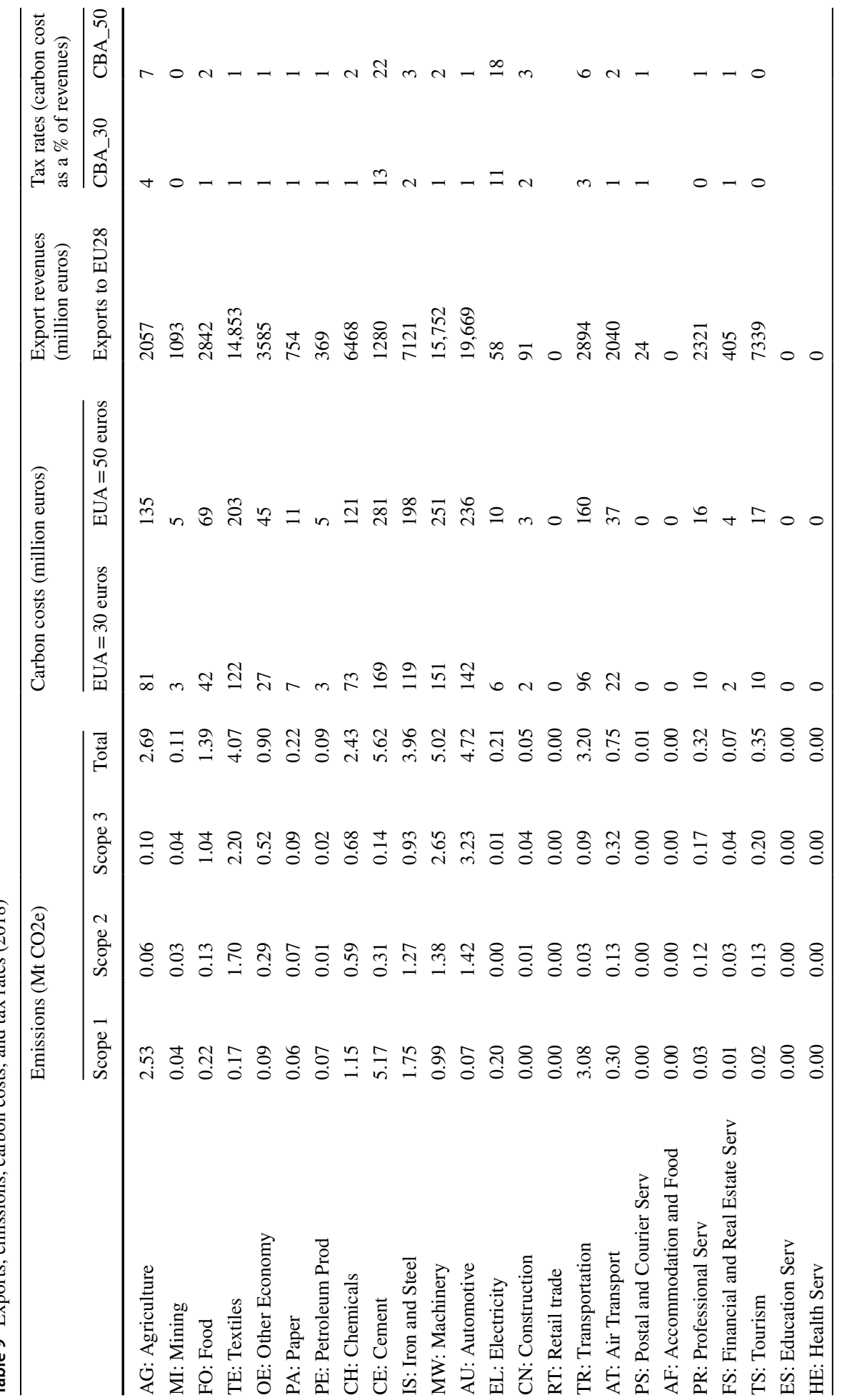




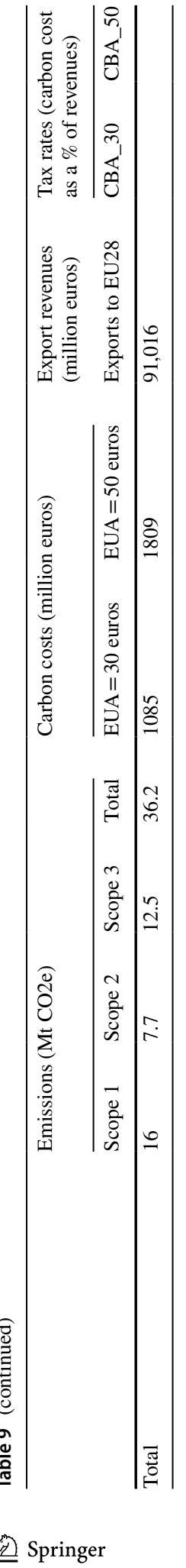


Table 10 Parameters of the labor market (2018)

\begin{tabular}{lll}
\hline & $\begin{array}{l}\text { Labor employment (thousand } \\
\text { workers) }\end{array}$ & $\begin{array}{l}\text { Total wages } \\
\text { (millions } 2018 \\
\text { TL) }\end{array}$ \\
& Total labor Emp & Total wages \\
\hline AG: Agriculture & $4,739.000$ & $19,836.196$ \\
MI: Mining & 150.000 & $103,929.964$ \\
FD: Food Processing & 610.158 & $56,497.962$ \\
TE: Textiles, Clothing & $1,241.675$ & $51,120.331$ \\
OE: Other Economy & $4,676.522$ & $280,667.178$ \\
PA: Paper Products & 144.412 & $7,786.640$ \\
PE: Petroleum Products & 10.380 & $1,686.809$ \\
CH: Chemicals & 409.504 & $10,077.691$ \\
CE: Cement & 305.010 & $10,921.630$ \\
IS: Iron and Steel & 172.456 & $7,553.612$ \\
MW: Machinery, White Goods & 990.347 & $36,599.741$ \\
AU: Automotive & 215.077 & $26,612.040$ \\
EL: Electricity & 288.000 & $8,761.482$ \\
CN: Construction & $1,972.000$ & $76,437.971$ \\
RT: Retail trade & $3,960.000$ & $38,340.916$ \\
TR: Transportation & $1,174.709$ & $84,232.204$ \\
AT: Air Transport & 295.028 & $22,266.918$ \\
PS: Postal and Courier Services & 93.460 & $6,087.943$ \\
AF: Accommodation and Food & $1,611.000$ & $51,869.097$ \\
PR: Professional Services & $1,336.826$ & $70,165.227$ \\
FS: Financial and Real Estate Services & $1,043.998$ & $48,914.279$ \\
TS: Tourism & 233.439 & $18,020.950$ \\
ES: Education Services & $1,682.000$ & $132,868.524$ \\
HE: Health Services & $1,383.000$ & $52,599.863$ \\
Total & $28,738.000$ & $1,223,855.169$ \\
\hline & &
\end{tabular}

\section{References}

Acar, S., Voyvoda, E., \& Yeldan, E. (2018). Macroeconomics of climate change in a dualistic economy: A regional general equilibrium analysis. Elsevier.

Acar, S., \& Gültekin-Karakaş, D. (2016). Questioning turkey's "miracle" growth from a sustainability perspective. Journal of Environment and Development, 25(2), 131-158.

Acar, S., \& Yeldan, E. (2016). Environmental impacts of coal subsidies in Turkey: A general equilibrium analysis. Energy Policy, 90, 1-15.

Alberici, S., Boeve, S., van Breevoort, P., Deng, Y., Förster, S., Gardiner, A., van Gastel, V., Grave, K., Groenenberg, H., de Jager, D., Klaassen, E., Pouwels, W., Smith, M., de Visser, E., Winkel, T., \& Wouters, K. (2014). Subsidies and Costs of EU Energy - Final Report and Annex 3, Ecofys.

Bouzaher, A., Şahin, Ş, \& Yeldan, E. (2015). How to go green: a general equilibrium investigation of environmental policies for sustained growth with an application to Turkey's economy. Letters in Spatial and Resource Sciences, 8(1), 49-76.

Climate Policy Initiative (CPI). (2019). In B. Buchner, A. Clark, A. Falconer, R. Macquarie, C. Meattle, R. Tolentino, \& C. Wetherbee (Eds.), Global landscape of climate finance. London. Available at: https:// climatepolicyinitiative.org/publication/global-climate-finance-2019/. 
European Commission. (2019). Communication from the commission to the european parliament, the european council, the council, the european economic and social committee and the committee of the regions: The european green deal. Available at https://ec.europa.eu/info/sites/info/files/europeangreen-deal-communication_en.pdf.

Helm, C., \& Schmidt, R. C. (2015). Climate cooperation with technology investments and border carbon adjustment. European Economic Review, 75, 112-130.

IMF. (2020). World economic outlook. Washington D.C.

Institute of International Finance. (2019). "Green-Weekly-Insight-Financing-a-Sustainable-Recovery”, available at IIF https://www.iif.com/Publications/ID/3931/Green-Weekly-Insight-Financing-a-Sustainable-Recov ery.

Kat, B., Paltsev, S., \& Yuan, M. (2018). Turkish energy sector development and the Paris Agreement goals: A CGE model assessment.

Marcu, A., Mehling, M., \& Cosbey, A. (2020). Border carbon adjustments in the EU: Issues and options. ERCST Report available at https://ercst.org/border-carbon-adjustments-in-the-eu-issues-and-options/.

Ministry of Treasury and Finance TR. (2020). The new economy programme, 2020. Ankara.

Neuhoff, K. (2011). Climate Policy after Copenhagen: The Role of Carbon Pricing. Cambridge University Press.

OECD. (2014). The upcoming slow down of the global economy in the next 60 Years. Paris.

OECD. (2019). Climate Finance Provided and Mobilised by Developed Countries in 2013-17. OECD Publishing, Paris,. https://doi.org/10.1787/39faf4a7-en

OECD. (2021). Effective Carbon Rates 2021: Pricing Carbon Emissions through Taxes and Emissions Trading. OECD Publishing, Paris,. https://doi.org/10.1787/0e8e24f5-en

PMR. (2018). Assessment of carbon leakage risk for turkey under carbon pricing policies. Vivid Economics. United Kingdom.

TÜSİAD. (2016). In E. Yeldan, A. A. Aşıcı, A. Yılmaz, B. Özenç, B. Kat, B. Ünüvar, E. Voyvoda, E. Turhan, F. Taşkın, G. N. Demirer, İ. Yücel, L. Kurnaz, Ö. İ. Çakmak, M. Ö. Berke, O. Balaban, P. İpek, R. Sarı, S. C. Mazlum, S. Acar, U. Soytaş, Ü. Şahin, V. ve Kulaçoğlu (Eds.), Ekonomi politikaları perspektifinden İklim değişikliği ile mücadele. İstanbul: TÜSİAD.

United Nations. (1993). Handbook of National Accounting; Handbook of Input-Output Table Compilation and Analysis, Series F, No. 74. United Nations. New York. http://unstats.un.org/unsd/publication/SeriesF/Serie sF_74E.pdf.

Voyvoda, E., Yeldan, E., Berke, M. Ö., Şahin, Ü., \& Gacal, F. (2015). Türkiye için Düşük Karbonlu Kalkınma Yollart ve Öncelikleri. WWF \& Sabancı University.

WRI and WBCSD. (2004). The greenhouse gas protocol. A Corporate Accounting and Reporting Standard. Revised Edition, 30 March 2004. https://ghgprotocol.org/sites/default/files/standards/ghg-protocol-revised. pdf.

Yeldan, E., Aşıcı, A. A., \& Acar, S. (2020). Ekonomi Göstergeleri Merceğinden Yeni İklim Rejimi [New Climate Regime through the Lens of Economic Indicators], TÜSİAD Report.

Publisher's Note Springer Nature remains neutral with regard to jurisdictional claims in published maps and institutional affiliations.

\section{Authors and Affiliations}

\section{Sevil Acar ${ }^{1} \cdot$ Ahmet Atıl Aşıcl $^{2}$ - A. Erinç Yeldan ${ }^{3}$}

A. Erinç Yeldan

erinc.yeldan@khas.edu.tr

Sevil Acar

sevil.acar@boun.edu.tr

Ahmet Atıl Aşıcı

asici@itu.edu.tr

1 Boğaziçi University, Istanbul, Turkey

2 Istanbul Technical University, Istanbul, Turkey

3 Kadir Has University, Istanbul, Turkey 